\title{
TOXICITY OF NICKEL AND CADMIUM IN SPRUCE SEEDLINGS: EFFECT OF SEPARATED AND COMBINED TREATMENTS ON PEROXIDASE AND SUPEROXIDE-DISMUTASE ACTIVITY
}

\author{
Ksenija Radotić1, Tanja Dučić1, Radivoje Prodanović2, Zoran Vujčić2, \\ Branko Karadžić3, Suetlana Antić-Jovanović 4 \\ ${ }^{1}$ Center for Multidisciplinary Studies, University of Belgrade, Kneza Višeslava 1, Belgrade \\ 2Faculty of Biochemistry, University of Belgrade \\ 3Institute for Biological Research »Siniša Stanković«, Belgrade \\ 4Faculty of Agriculture, University of Belgrade
}

\begin{abstract}
Summary: We studied the soluble peroxidase and superoxid-dismutase activity, peroxidase isoenzyme pattern and metal content in the needles of 2-year-old spruce grown on soils supplemented with cadmium and nickel concentrations from 3 to $30 \mathrm{mg} \mathrm{kg}{ }^{1}$ and 50 to $500 \mathrm{mg} \mathrm{kg}^{1}$ respectively. The two metals were applied both separately and simultaneously. The kinetics of metal assimilation and total accumulated quantity depended on the type of treatment. Following metal exposure, an increase in peroxidase activity in the seedlings treated with $\mathrm{Cd}$ and $\mathrm{Ni} / \mathrm{Cd}$, and in superoxide-dismutase activity during $\mathrm{Ni} / \mathrm{Cd}$ treatment was observed. A parallel change of peroxidase isoenzyme pattern occurred. There was a good correlation between accumulated metals in needles and enzyme activities. The effect of $\mathrm{Cd}$ on the measured parameters was shown to be stronger comparing to the effect of Ni. The results obtained show that peroxidase and superoxide-dismutase activity and peroxidase isoenzyme pattern could be used to evaluate the capacity of one part of the defense system in spruce seedlings to withstand metal stress.
\end{abstract}

Key words: free radicals, enzyme induction, bioindication

\section{Introduction}

Biochemical responses of plants to heavy metals are complex. Metals can induce oxidative stress directly or indirectly, by interaction with biochemical redox processes. Above a certain threshold of metal concentration in the cell, the physiological state of the cell is reversibly changed (1). This response is reflected in an increase in the capacity of certain enzymes, known as enzyme induction. These secondary, indirect metal effects are considered as to play an important role in the stress metabolism induced by toxic metal concentrations (2). Peroxidase (POD) induction was observed in leaves of various plant species after application of

\footnotetext{
Address for correspondence

Dr Ksenija Radotić

Center for Multidisciplinary Studies of the University of Belgrade Kneza Višeslava 1

11000 Belgrade, Yugoslavia
}

toxic amounts of $\mathrm{Cd}$ and $\mathrm{Ni}$. This induction of POD capacity is strongly correlated with the plant tissue level of Cd (1). POD capacity of tree leaves was even utilized as a parameter for monitoring and mapping air pollution (3). Enhancement of POD capacity and appearance of the new isoforms is generally considered as an important criterion for senescence (2). Cardinaels found significant stimulation of the Mn-SOD with $\mathrm{Cd}$ in primary leaves Phaseolus vulgaris, and inhibition of $\mathrm{Cu} / \mathrm{Zn}-\mathrm{SOD}$ (4). A wide array of metals, including $\mathrm{Cd}$ and $\mathrm{Ni}$, induce phytochelatin production, but the binding of metals to phytochelatins has, as yet, only been demonstrated for $\mathrm{Cd}, \mathrm{Cu}$ and $\mathrm{Pb}(5,6)$. Gawel suggested that phytochelatin is a good indicator of metal stress in forest decline species (7).

In the published literature the effect of stress induced by heavy metals has been predominantly studied in plants either taken from field $(8,9)$ or grown in controlled conditions on hydroponic nutrient solutions $(10,11)$. There were few results on spruce grown in 
controlled environmental conditions on the soil (12). In this work we studied the activity of intracellular and extracellular soluble POD and SOD, as well as metal content in the needles of spruce grown in controlled conditions, on the soil supplemented with different cadmium and nickel concentrations. The metals were added both individually or simultaneously. This study was designed to investigate the difference between separated and combined metal treatments. We also aimed to see whether there is interdependence of $\mathrm{Cd}$ and $\mathrm{Ni}$ accumulation in the spruce needles exposed to combined $\mathrm{Cd} / \mathrm{Ni}$ stress, as well as the change in total POD and SOD activity. Using canonical correspondence analysis (CCA) in case of combined treatments, we tried to evaluate which of the applied metals has stronger effect on the measured parameters, as well as which of the measured parameters is most influenced by the metal stress.

Due to the presence of many modifying environmental factors, it is almost impossible to study the response of spruce needles to cadmium and nickel in adult plants in the field. Therefore, we have examined the response of the spruce seedlings to a range of $\mathrm{Cd}$ and Ni concentrations in controlled conditions. This study could particularly contribute to the knowledge on the effect of $\mathrm{Cd}$ and $\mathrm{Ni}$ on the plant antioxidative enzymes, and more generally, to see whether the activity of these enzymes may be used as a potential biomarker to extreme factors such as high concentration of heavy metals in the soil. These studies may be used to establish parameters of biological monitoring programs conducted under environmental conditions (13).

\section{Materials and Methods}

\section{Plant growth and treatment}

In the experiments we used 2-year-old spruce seedlings (Picea abies L.) grown in the greenhouse. Seedlings were transferred from the nursery to the greenhouse and grown singly in pots of $300 \mathrm{~mL}$ volume, in daylight and temperature between 20 and $25^{\circ} \mathrm{C}$. The seedlings were grown on a soil composed of peat and compost $(4: 1 \mathrm{v} / \mathrm{v})$ mixed with quartz sand $(3: 1 \mathrm{v} / \mathrm{v})$. $\mathrm{pH}$ value of the soil was 6.6 before treatment. Soil was analyzed for the presence of $\mathrm{Cd}$ and Ni prior to the planting and no increased concentrations of the metals were detected. The treatment of the seedlings was started 30 days after their planting. During one week $100 \mathrm{~mL}$ of $0.25 \mathrm{~mol} / \mathrm{L} \mathrm{H}_{2} \mathrm{SO}_{4}$ was supplied to the soil in the pots where plants were grown, lowering its $\mathrm{pH}$ value to 5.8. Acidification of the soil facilitates metal uptake by the plants. These acid-treated plants were taken as control (B). Under natural conditions, soil acidification (through soil pollution by acidic rain) increases metal uptake by plants, and as such may be a precondition of their pronounced effect on plants. After two weeks, different $\mathrm{Ni}$ and $\mathrm{Cd}$ concentrations were added to the soil, separately or simultaneously, in the form of $\mathrm{CdSO}_{4}$ and $\mathrm{NiSO}_{4}$. Metals were applied in concentrations equal to the maximally permitted for the soil (C1): 3 ppm for Cd and 50 ppm for Ni (according to International Union of Biological Sciences), as well as five (C2) and ten times higher (seven times higher in the case of $\mathrm{Cd}$ separated treatment) (C3). After treatment the soil was watered with tap water. Seedlings were harvested after 1,2, 15, 30 and 60 days of metal treatment. All treatments were done in a period from March to May. Plants used for the experiments were healthy, without any exogenous infection detected. Needles from the whole plant were used as experimental material. The influence of metal ions on the metal content in the needles was monitored during 2 months after treatment, using AAS.

\section{Heavy metal determination in needles}

For metal determination, needles were dried at $70{ }^{\circ} \mathrm{C}$ for $12 \mathrm{~h}$, and ashed in a muffle furnace at $450 \pm$ $50{ }^{\circ} \mathrm{C}$ for $6 \mathrm{~h}$. The ash was dissolved in $2 \mathrm{~mL} \mathrm{HNO}_{3}$ $(1: 3 \mathrm{v} / \mathrm{v})$, evaporated and dried at $450 \pm 50{ }^{\circ} \mathrm{C}$ for $1 \mathrm{~h}$. For measurement the ash was dissolved in $2 \mathrm{~mL} \mathrm{HCl}$ $(1: 3 \mathrm{v} / \mathrm{v})$ and metal content was determined using flame atomic absorption spectrophotometer (Varian AA-10). The calculated detection limit was $0.023 \mathrm{mg}$ $\mathrm{mL}^{1}$ for $\mathrm{Cd}$ and $0.120 \mathrm{mg} \mathrm{mL}{ }^{1}$ for $\mathrm{Ni}$.

\section{Statistical analysis of data}

Each experimental variant and control was represented by four seedlings, which were treated as replicates. Statistical analysis of the enzyme activities end metal concentration data was performed using the Mann-Whitney $U$ ranking test, at the 0.05 level of significance. Canonical Correspondence Analysis (14) was performed using the »FLORA« package (15), to estimate which of the applied metals has the strongest effect on the studied enzymes and total protein content, as well as to see which enzyme has the most pronounced response to the increased metal concentrations.

\section{Determination of enzyme activities}

Extraction of soluble POD and SOD was performed by homogenization of needles in the medium (0.1 mol/L TRIS-HCl buffer $\mathrm{pH} \mathrm{7.8,} \mathrm{containing} 1$ $\mathrm{mmol} / \mathrm{L}$ dithiothreitol and $1 \mathrm{mmol} / \mathrm{L}$ EDTA) in 1:5 ratio $(\mathrm{w} / \mathrm{v})$, according to the procedure of Weckx and Clijsters (16). The homogenate was squeezed through eight gauze layers and centrifuged at $12000 \times \mathrm{g}$ and $4^{3} \mathrm{C}$ for $10 \mathrm{~min}$. The supernatant was used for POD activity measurements.

SOD activity was determined spectrophotometrically measuring the percent of the SOD-induced inhibition of adrenalin autooxidation at the alkaline $\mathrm{pH}$ 
(17), in a total volume of $3 \mathrm{~mL}$. Adrenalin stock solution was freshly prepared before the measurement and contained $3 \times 10^{4} \mathrm{~mol} / \mathrm{L}$ adrenalin in $0.1 \mathrm{~mol} / \mathrm{L} \mathrm{HCl}$. The assay mixture contained $0.05 \mathrm{~mol} / \mathrm{L}$ sodium carbonate buffer $\mathrm{pH}$ 10.2, $110^{4} \mathrm{~mol} / \mathrm{L}$ EDTA, $0.1 \mathrm{~mL}$ adrenalin stock solution and various amounts of enzyme preparations. Adrenalin autooxidation was monitored using Shimadzu UV-160 spectrophotometer at $480 \mathrm{~nm}$, during 10 minutes at $2630^{\circ} \mathrm{C}$. The rate of adrenalin autooxidation in the enzyme absence was taken as the reference value.

POD activity was determined spectrophotometrically with guaiacol as the substrate in a total volume of $3 \mathrm{~mL}$. The assay mixture contained $50 \mathrm{mmol} / \mathrm{L}$ acetate buffer pH 5.5, $92 \mathrm{mmol} / \mathrm{L}$ guaiacol, $18 \mathrm{mmol} / \mathrm{L} \mathrm{H}_{2} \mathrm{O}_{2}$ and variable amounts of the enzyme preparations. The turnover of guaiacol was monitored at $470 \mathrm{~nm}$ using Shimadzu UV-160 spectrophotometer. Reaction rate was calculated from the extinction coefficient for guaiacol of $25.5 \mathrm{mmol}^{1} \mathrm{~cm}^{1}$.

The enzyme activities were referred to the protein concentration in the extract.

Total protein concentration was determined by the method of Bradford (18) with bovine serum albumin as the standard.

All enzyme activities and protein concentrations in the treated seedlings were expressed as a percent of corresponding values for the untreated plants.

\section{Isoelectric focusing of soluble peroxidases}

Soluble POD isoenzymes were separated in a $\mathrm{pH}$ gradient from 3 to 9 (using 3\% ampholite solution) on a $5 \%$ polyacrylamide gel. POD isoenzymes were stained on gel with $20 \mathrm{mmol} / \mathrm{L}$ guaiacol and $5 \mathrm{mmol} / \mathrm{L}$ $\mathrm{H}_{2} \mathrm{O}_{2}$ in Na-acetate buffer pH 5.5 for 10 min at $25^{\circ} \mathrm{C}$.

\section{Results}

Nickel applied individually did not produce any damage to the seedlings. On the contrary, cadmium applied both individually and in combined treatments with nickel, caused visible symptoms of the injury of seedlings exposed to C2 and C3 concentration of heavy metals. Wilting of the needles was observed in about $1020 \%$ of seedlings after sixty days.

\section{Metal content in the needles}

Separated $\mathrm{Ni}$ and $\mathrm{Cd}$ treatments. Ni content in the spruce needles increased in parallel with Ni concentration in the soil (Figure 1a). Significantly higher Ni concentration, in comparison with untreated seedlings, was recorded after 15 days of treatment in plants exposed to $\mathrm{C} 3$ doze, and in plants treated 60 days with
C3 doze. Accumulated Ni concentrations in the needles were in the range 6 to $32 \mathrm{mg} / \mathrm{kg}$ DW (Figure 1a).

$\mathrm{Cd}$ content in the needles, similarly to the $\mathrm{Ni}$ treatment, increased with the increase of $\mathrm{Cd}$ concentration in the soil (Figure 1b). Significantly higher $\mathrm{Cd}$ concentration, in comparison with untreated seedlings, was recorded in plants treated 15 days with C2 doze, as well as after 30 and 60 days of treatment with $\mathrm{C} 2$ and $\mathrm{C} 3$ doze. Accumulated $\mathrm{Cd}$ concentrations in the needles were in the range 0.8 to $5.5 \mathrm{mg} / \mathrm{kg} \mathrm{DW}$ (Figure 1b).

Combined $\mathrm{Ni} / \mathrm{Cd}$ treatment. Cd was assimilated in considerably lower concentration in comparison with $\mathrm{Ni}$, which is in accordance with its lower soil concentrations. The highest concentration of both heavy metals in the needles was observed 15 days after plant exposure to C2 and C3 doze (Figure $1 \mathrm{c}, d$ ). There was no significant difference of $\mathrm{Cd}$ content in the needles in comparison with untreated plants (Figure 1c). A significantly higher $\mathrm{Ni}$ content in the needles was observed in the case of plants treated 15 days with $\mathrm{C} 2$ doze and 60 days with $\mathrm{C} 3$ doze of $\mathrm{Ni} / \mathrm{Cd}$, in comparison with untreated plants (Figure 1c). Accumulated $\mathrm{Cd}$ concentrations in the needles were in the range 0.4 to $2.9 \mathrm{mg} / \mathrm{kg}$ DW (Figure $1 \mathrm{~d}$ ) and $\mathrm{Ni}$ was in the range 5.3 to $44 \mathrm{mg} / \mathrm{kg} \mathrm{DW}$ (Figure 1c). There is a similar kinetics of metal absorption in case of $\mathrm{Cd}$ and Ni: the highest metal accumulation in the needles was detected after 15 days of treatment (Figure $1 c, d$ ). The highest metal concentration was measured in plants treated with the highest metal concentration in the soil (C2 and $\mathrm{C} 3$ ).

\section{Effect of metal treatment on protein concentration and enzyme activities in the needles}

Protein concentration. There was no significant difference in protein concentration in the needles throughout separated Ni and Cd treatments, in comparison with untreated plants (Figure 2a, b). In case of Ni treatment the exception was significantly lower protein content after 1 day treatment with $\mathrm{C} 2$ doze and significantly higher one after 60-day treatment with $\mathrm{C} 3$ doze (Figure $2 \mathrm{a}$ ). In seedlings treated with $\mathrm{Cd}$ alone, only after 60 day treatment with $\mathrm{C} 1$ doze, protein content was significantly lower than in untreated plants (Figure $2 b$ ).

In plants treated simultaneously with $\mathrm{Ni}$ and $\mathrm{Cd}$, the protein concentrations were significantly higher in plants treated 1 day with $\mathrm{C} 1$ and 60 days with $\mathrm{C} 2$ and C3 concentrations in comparison with untreated plants (Figure 2c). 


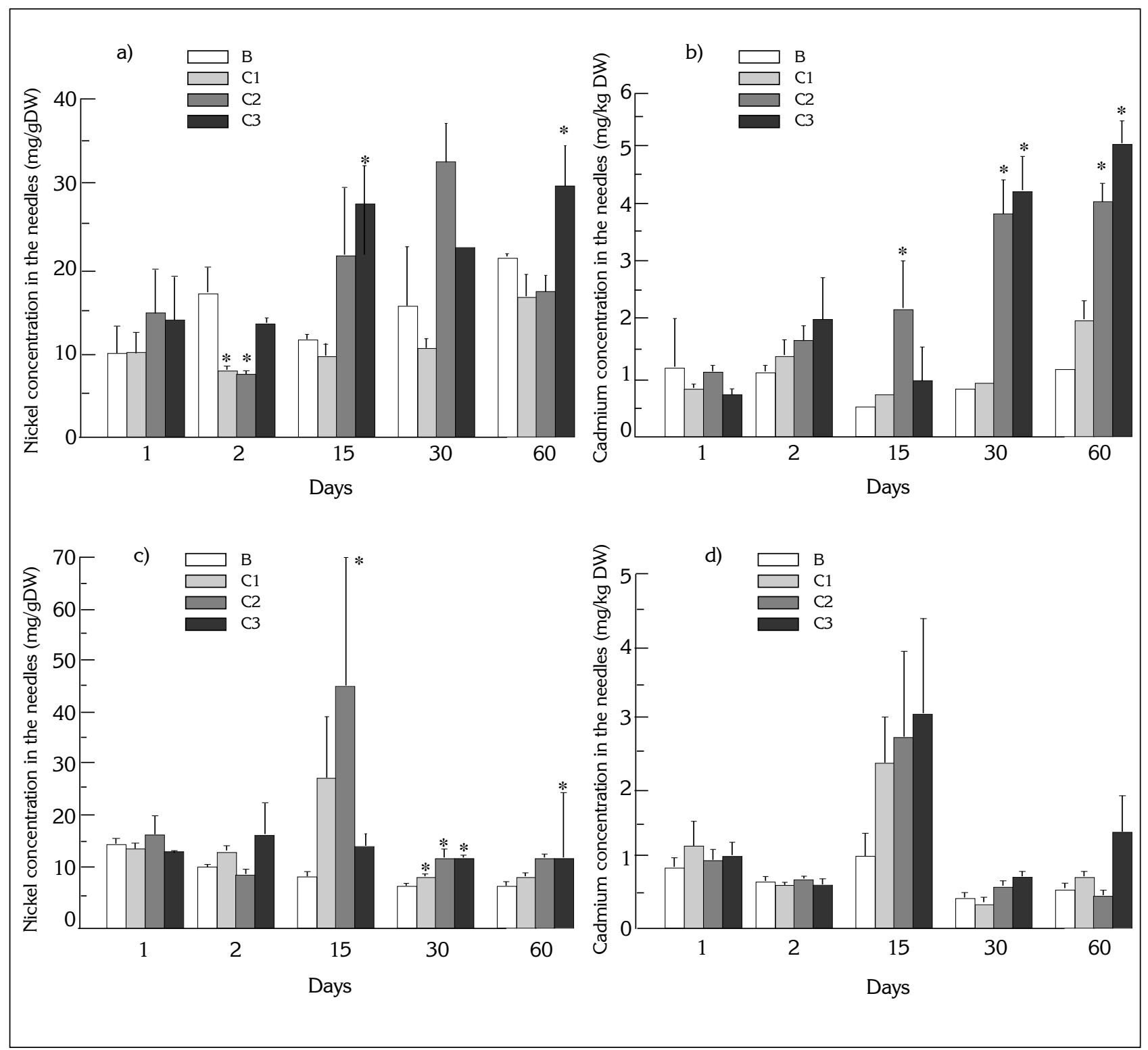

Figure 1. Dependence of the nickel (a), cadmium (b), nickel and cadmium (c,d) concentration in the spruce needles on the applied cadmium and nickel concentrations in the soil, for different duration of nickel (a), cadmium (b) and combined $\mathrm{Ni} / \mathrm{Cd}$ (c,d) treatment. B untreated plants; C1, C2, C3 50/3, 250/15 and 500/30 mg kg ${ }^{1} \mathrm{Ni} / \mathrm{Cd}$, respectively.

The bars indicate S.E. * statistically significant difference in metal concentration in comparison with untreated plants.

Peroxidase. As in case of protein concentration, there was no significantly different POD specific activity in the needles throughout the treatment with $\mathrm{Ni}$ alone, in comparison with untreated plants. After longterm treatments POD activity decreased comparing to untreated plants. Only in 15 days treated plants POD activity was significantly lower comparing to the control (Figure 3a). In the seedlings treated for 2 days with C2 doze of Cd, a statistically significant increase of POD activity in relation to the untreated plants was found. In the case of addition of $\mathrm{C} 1 \mathrm{C} 3$ doze of $\mathrm{Cd}$ to the soil, a statistically significant increase in POD activity was found in comparison to the control 15 days after treatment. In 30-day treated plants a significant increase in POD activity was observed in the case of C2 doze (Figure 3b).

After short-term and 60-day treatment simultaneously with $\mathrm{Ni}$ and $\mathrm{Cd}$, a decrease in specific POD activity in comparison with metal untreated plants was observed (Figure 3c). Significant increase in POD activity was observed only after 30-day treatment. 


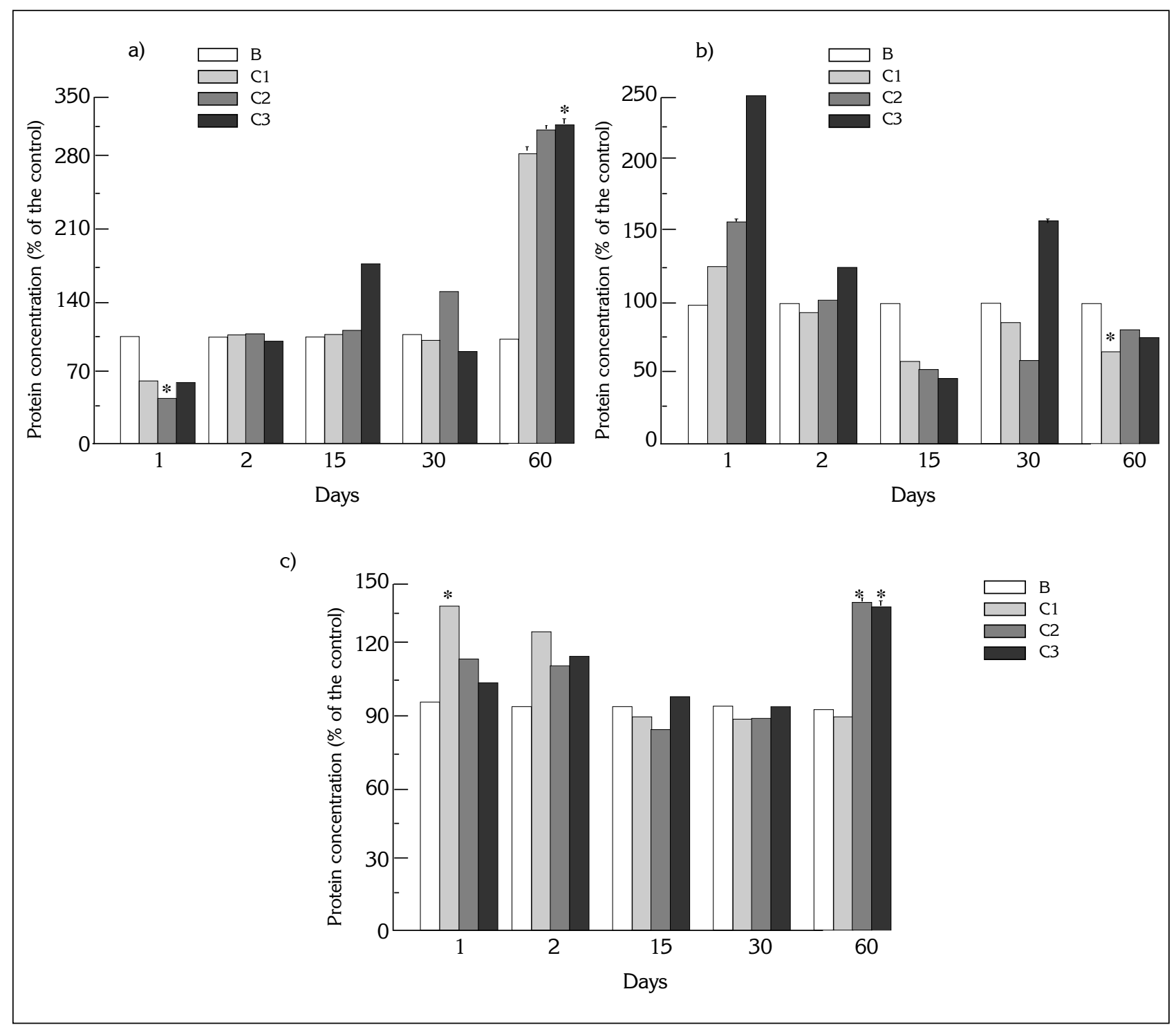

Figure 2. Total soluble protein concentration in the spruce needles, as a function of nickel (a), cadmium (b) and Ni/Cd (c) treatment duration. * Statistically significant difference in metal concentration in comparison with untreated plants..

Superoxide-dismutase. In nickel treated needles, SOD activity was significantly higher after 1 day of treatment with all three Ni concentrations, in comparison with untreated seedlings. SOD activity was significantly lower, comparing to the untreated plants, after 30 days of treatment with C3 doze (Figure 4a).

In case of combined $\mathrm{Ni} / \mathrm{Cd}$ treatment, a decrease in specific SOD activity after short-term treatments, and an increase after long-term treatments, was observed in comparison with untreated plants (Figure $4 c)$. There were significant activity differences in case of 30-day treatment with C3 and 60-day treatment with $\mathrm{C} 1$ concentration, in comparison with untreated plants.

\section{Isoelectrofocusing of the peroxidase from the needles}

To investigate whether the change of POD activity in the needles during metal treatment is associated with specific POD isoenzymes, we performed IEF of the needle extracts. We detected two groups of POD isoenzymes: acidic and basic. During all treatments only changes in the acidic isoenzyme patterns were detected (Figure 5). Since POD activity focused at the end of the gel, it remains unknown what the true pI value of the acidic peroxidase(s) was. However, in all treatments similar changes in isoenzyme profile were detected: disappearance of certain isoenzymes and appearance of the new ones in time with increasing metal concentration in the soil. In case of all treat- 


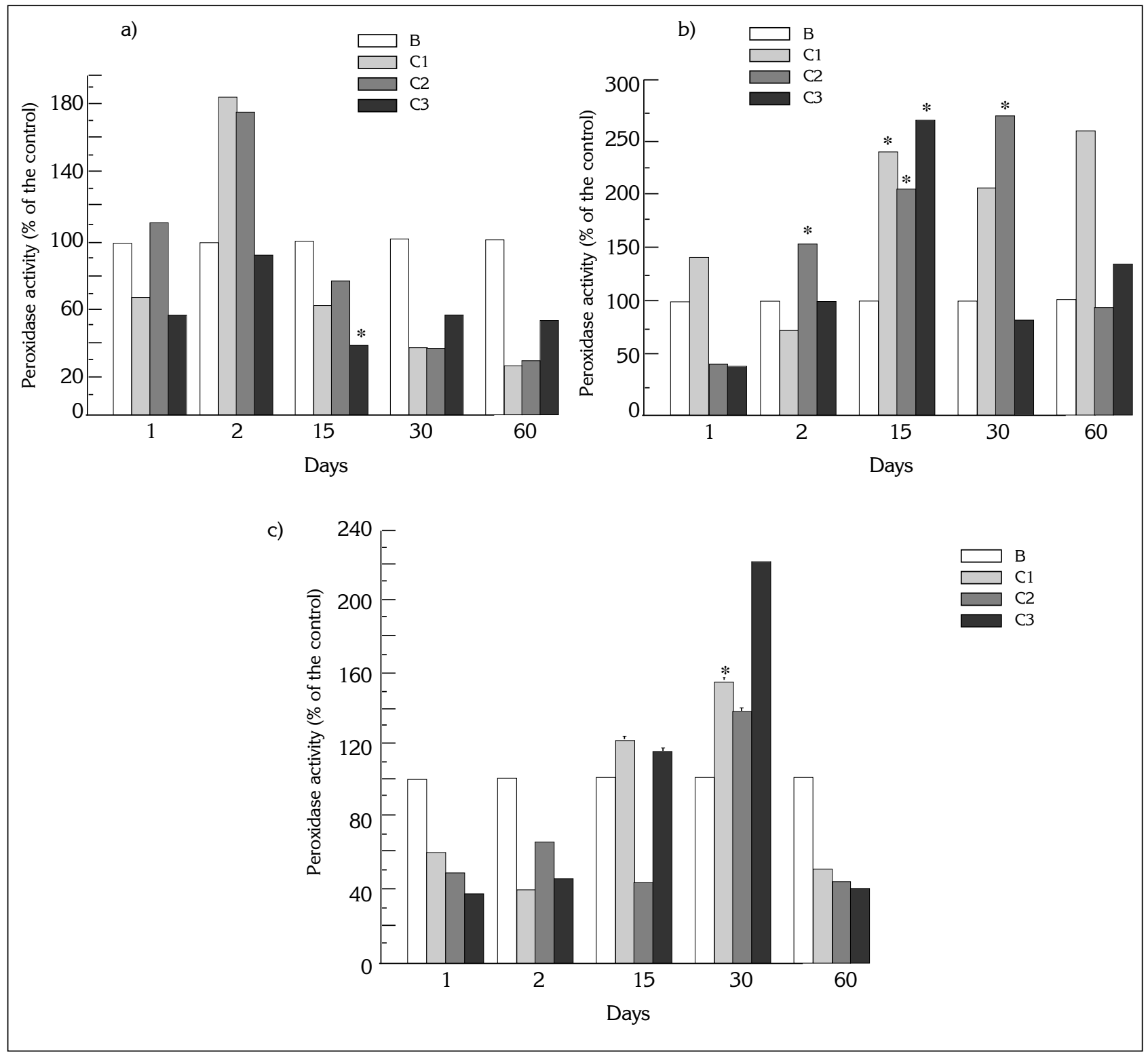

Figure 3. Specific activity of soluble peroxidases from spruce needles as a function of treatment duration, after exposure to 50 (C1), 250 (C2), 500 (C3) $\mathrm{mg} \mathrm{kg}^{1}$ nickel (a); 3 (C1), 15 (C2), 21 (C3) $\mathrm{mg} \mathrm{kg}{ }^{1}$ cadmium (b) and 50/3 (C1), 250/15 (C2) and 500/30 (C3) $\mathrm{mg} \mathrm{kg}^{1} \mathrm{Ni} / \mathrm{Cd}$ (c); B metal untreated leaves.

* Statistically significant difference in metal concentration in comparison with untreated plants.

ments, the new isoenzymes appeared during shortterm treatment in case of C2 and C3 dozes. After longterm treatments, certain isoenzymes disappeared and the additional ones appeared in case of all three applied metal concentrations.

\section{Canonical correspondence analysis of metal content and enzyme activities in the needles}

In the case of untreated plants $\mathrm{Cd}$ and $\mathrm{Ni}$ had independent effect on all measured parameters: enzyme activity of SOD and POD, total protein con- tent. This case refers to the natural content of these metals in needles, when there is no metal increase in the soil. Relating to the first axis, considerable deviations between measured parameters (POD and SOD activity, protein content) were observed (Figure 6a). The separation of POD and SOD activities and protein concentration along the first CCA axis is almost perpendicular with respect to the position of $\mathrm{Ni}$ and $\mathrm{Cd}$ vectors. This clearly indicates that, in untreated plants, $\mathrm{Ni}$ and $\mathrm{Cd}$ have insignificant effects on both POD and SOD activities and protein concentration.

In the case of plants treated with $\mathrm{C} 1$ doze, on the basis of the vector position, the two metals have syn- 


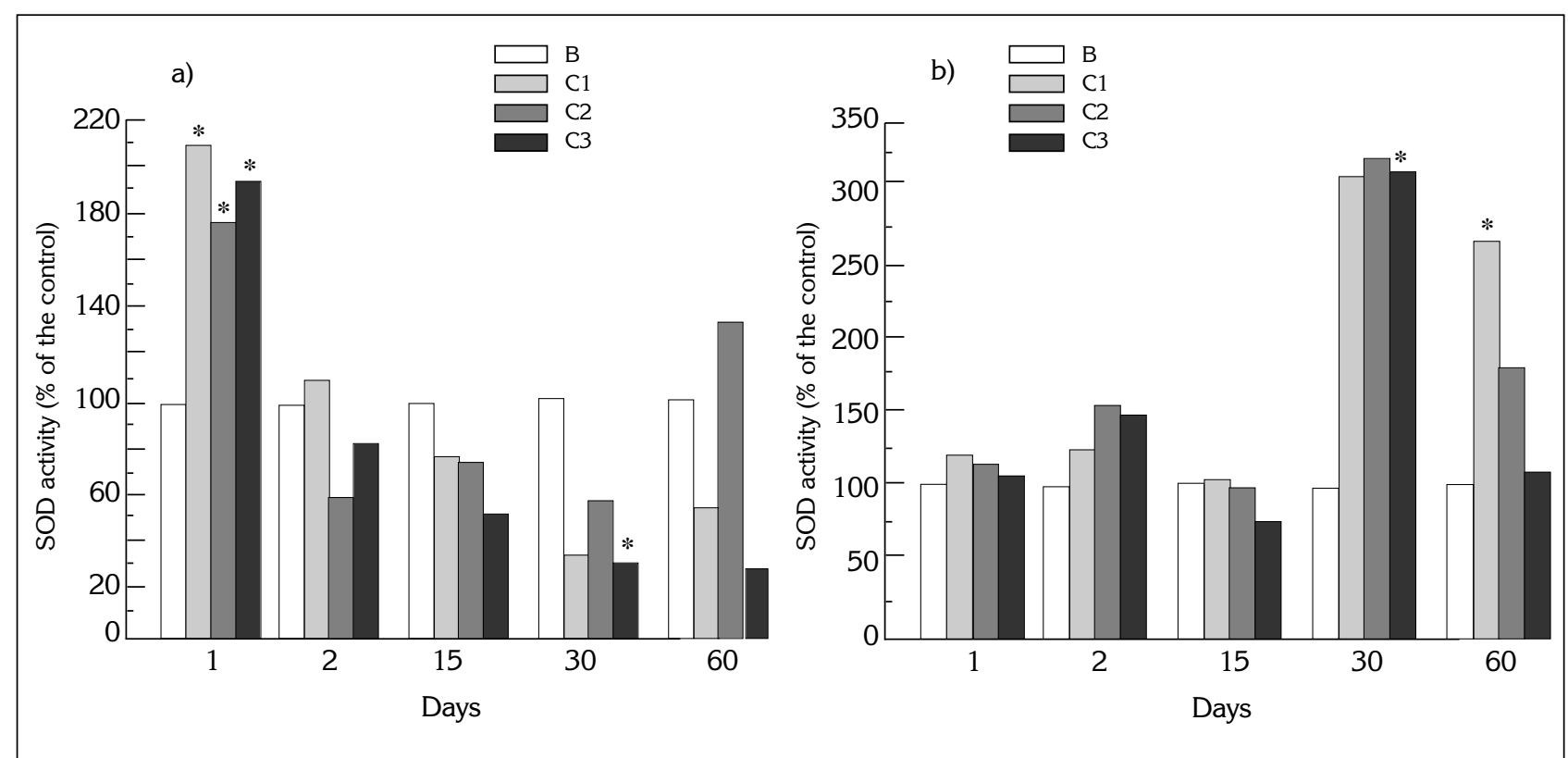

Figure 4. Specific activity of soluble SOD from spruce needles as a function of treatment duration, after exposure to 50 (C1), 250 (b), 500 (C3) $\mathrm{mg} \mathrm{kg}^{1}$ nickel (a) and 50/3 (C1), 250/15 (C2) and 500/30 (C3) mg kg ${ }^{1} \mathrm{Ni} / \mathrm{Cd}$ (b); B metal untreated leaves. * Statistically significant difference in metal concentration in comparison with untreated plants.

ergistic effect on the enzyme activities and protein content (Figure 6b). Cd has a more pronounced effect on the measured parameters in comparison with $\mathrm{Ni}$. Referring to the first axis, the greatest difference between individual parameters was observed in the case of POD activity and protein content. Referring to the second axis, most significant difference could be observed in case of POD activity. Again, $\mathrm{Ni}$ and $\mathrm{Cd}$ vectors were almost perpendicular on the direction of main variation of both POD and SOD activities and the protein content.

The synergistic effect between $\mathrm{Ni}$ and $\mathrm{Cd}$ is even more pronounced in plants treated with $\mathrm{C} 2$ doze and effect of $\mathrm{Cd}$ is again dominant in comparison with $\mathrm{Ni}$ (Figure 6c). Referring to the first axis, the greatest data deviation between individual parameters could be observed in protein content. Considering C2 doze, the position of $\mathrm{Ni}$ and $\mathrm{Cd}$ vectors approaches to the direction of the main variation of analyzed components. This indicates that $\mathrm{C} 2$ doze caused more pronounced effects of Ni and Cd on both POD and SOD activities and protein concentration.

In the case of highest applied metal concentration, C3, the influence of $\mathrm{Ni}$ and $\mathrm{Cd}$ is antagonistic. The effect of $\mathrm{Cd}$ in this case is more pronounced in comparison with the effect of Ni. Both metals have almost equal influence on the two axes (Figure 6d). Referring to both axes, the greatest data differences between individual parameters could be seen in protein content. Position of $\mathrm{Ni}$ and $\mathrm{Cd}$ vectors almost perfectly corresponds with direction of the main variation of protein concentration, POD activity and SOD acti- vity. This indicates that at $\mathrm{C} 3$ doze both $\mathrm{Ni}$ and $\mathrm{Cd}$ have significant effects on protein concentration as well as SOD and POD activities.

\section{Discussion}

Increase of the level of accumulated metals in the soil is not always followed by their high concentration in the plant (19). Progressive accumulation of heavy metals in the plants and their toxic level in the soil depend on various physical and chemical soil parameters, plant species and heavy metal characteristics. Increase of the level of accumulated metals in the plant above their internal threshold can induce irreversible changes. A general plant response to stress is activation of the system of antioxidative defense, which prevents each cell component from oxidative injury. One of the cell responses to the increased metal concentration in the environment is the increase in the capacity of antioxidative enzymes such as POD, SOD, catalase (2). The change of antioxidative enzyme level in a plant depends on duration of plant exposure to the metal stress and on metal concentration.

According to our results, there is a different kinetics in metal assimilation depending on the type of treatment. In separated treatments there is an increase in $\mathrm{Ni}$ and $\mathrm{Cd}$ content in the needles with the time of exposure to the metal in the soil. In combined $\mathrm{Ni} / \mathrm{Cd}$ treatment the lower total quantity of cadmium and higher total quantity of nickel is assimilated in the plants comparing to the separated treatments, and the maximal accumulation of both metals is attained after 


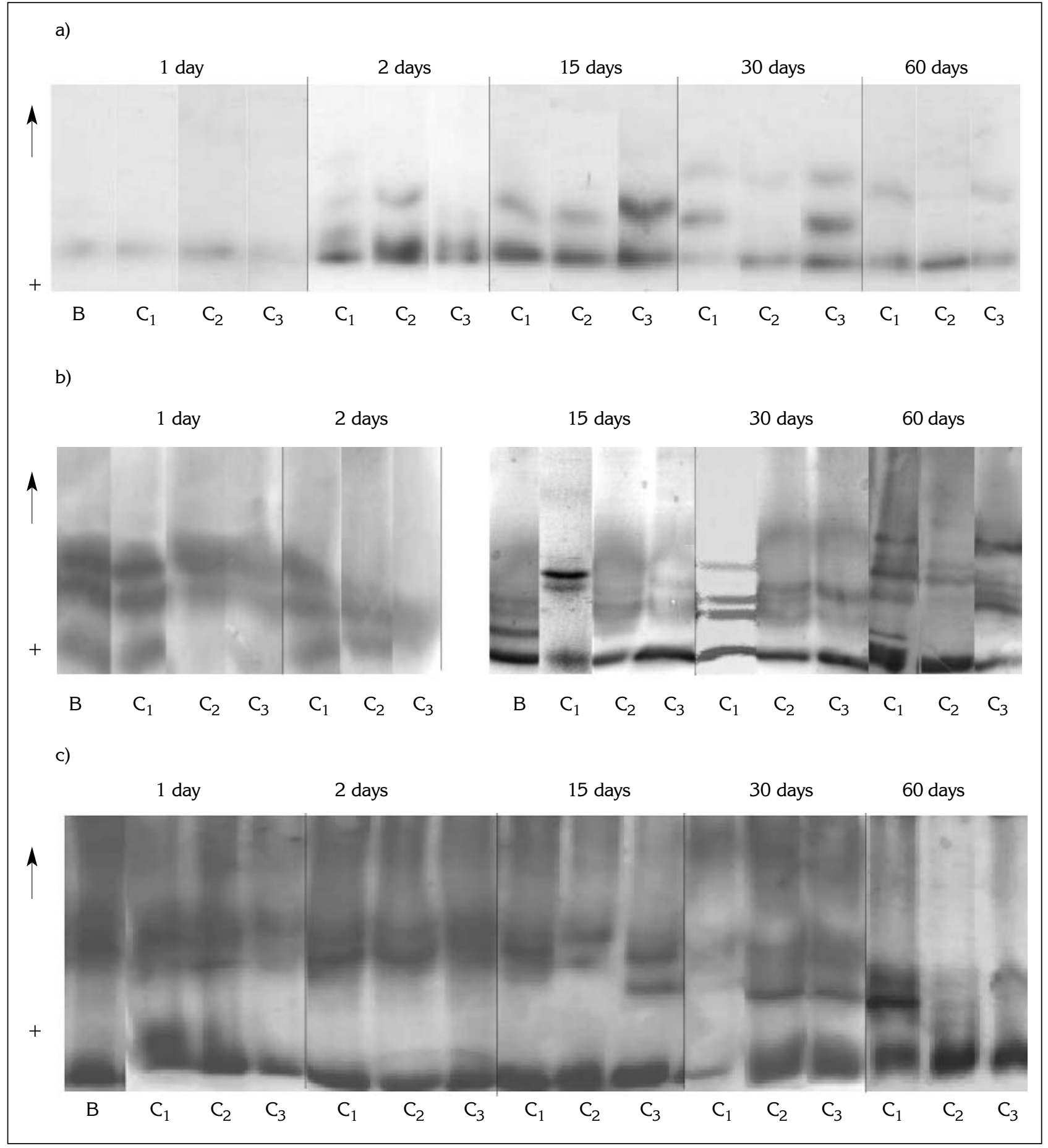

Figure 5. Isoelectrofocusing of soluble peroxidases in a pH gradient from 3 to 9: (a) nickel, (b) cadmium, (c) $\mathrm{Ni} / \mathrm{Cd}$ treatment. The figure is composed from representative lanes of several gels. Labeling is as in Figure1.

15- day treatment (Figure 1). This shows that there is an interaction between the two metals when applied simultaneously. The lower total quantity of accumulated cadmium in the needles in presence of nickel may have positive consequences in plant protection from cadmium, one of the most harmful metals of antropogenic origin.
An increase in $\mathrm{H}_{2} \mathrm{O}_{2}$ and organic peroxide production during stress action induces POD synthesis in plants. POD induction is a general response of higher plants to the assimilation of toxic dozes of heavy metals $(20,21)$. Metal-induced production of ROS in plant tissues directly affects SOD activity. It was shown that SOD has a role in the stress tolerance of plants (22). 


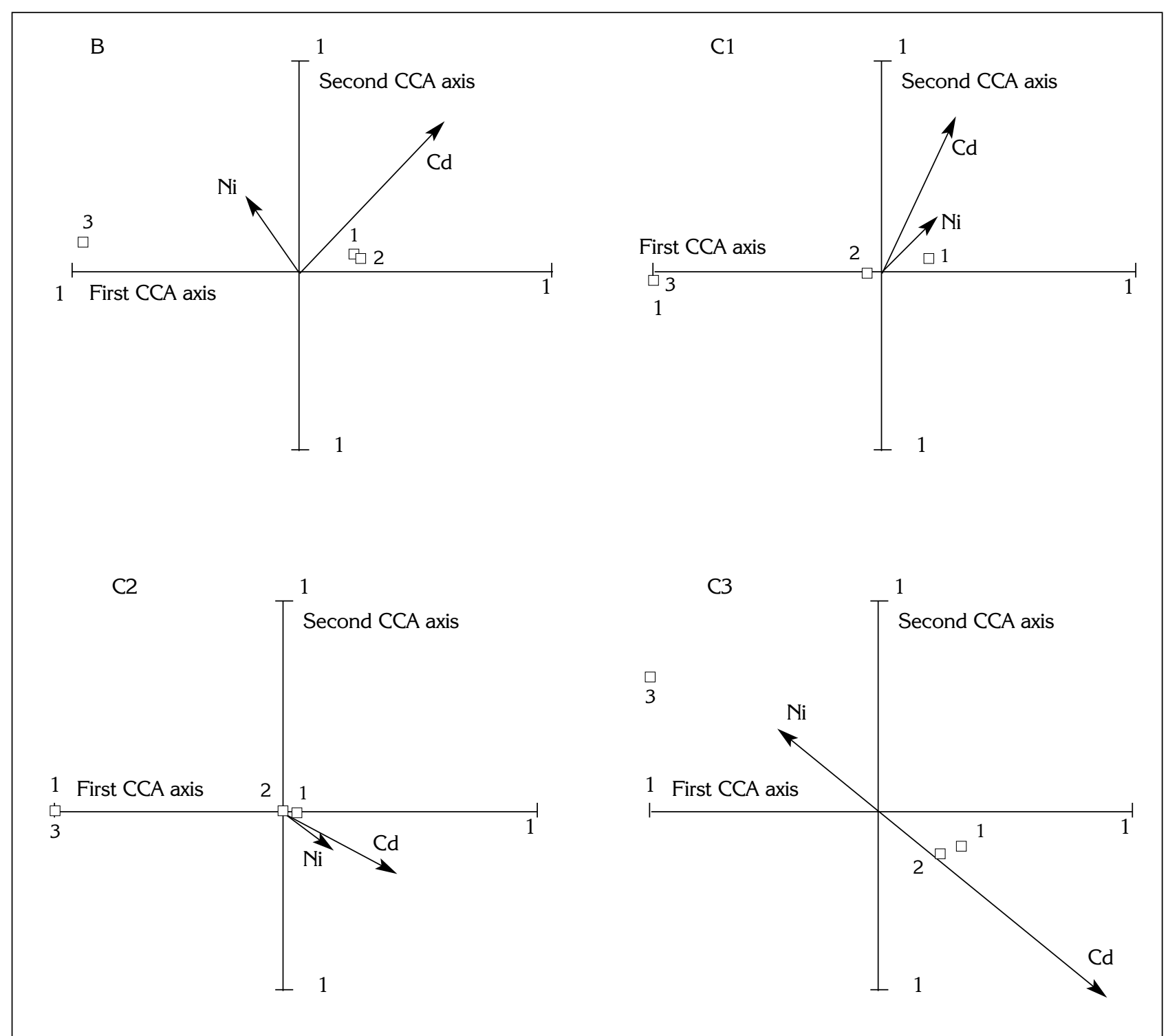

Figure 6. Canonical correspondence analysis for untreated spruce needles (a) and needles treated with 50/3 (b), 250/15 (c) and 500/30 (d) $\mathrm{mg} \mathrm{kg}^{1} \mathrm{Ni} / \mathrm{Cd}$. 1 soluble POD, 2 soluble SOD, 3 proteins.

SOD is one of the first enzymes induced under stress conditions, because substrate for this enzyme, O2. as a first arising ROS species starts free-radical reactions (23).

Though in short-term treatments accumulated metal concentration in the needles was at the level of the control, the early changes were detected in the protein concentration after 1 day of $\mathrm{Ni}$ and $\mathrm{Ni} / \mathrm{Cd}$ treatment (Figure 2) with certain metal concentrations. The change in POD activity in the needles 2-day treated with Cd, as well as in SOD activity in case of 1-day Ni treatment (Figure $4 \mathrm{c}$ ), also reflected the early reaction of the seedlings to the metal stress. The change in POD isoenzyme pattern after 1 and 2 days of both separated and combined treatment (Figure 5), is also an early-detectable reaction to stress. These results show that biochemical parameters, in this case IEF pattern and SOD activity, can be an indicator of stress before statistically significant quantity of the pollutant is present in the plant.

The results of long-term, both separated and combined, treatments showed that increasing metal concentration induced a reaction of the antioxidative defense system in the seedlings, alleviating the toxic effect of metal ions. The increase in POD activity in the seedlings treated with $\mathrm{Cd}$ and $\mathrm{Ni} / \mathrm{Cd}$ (Figure 3), as well as in SOD activity during Ni/Cd treatment (Figure 4), is probably related to the oxidative reactions corresponding to an increase in peroxides and free radicals in the plant cells. Activation of oxygen has been proposed as a general reaction on several stress factors including metals, and reactive oxygen forms could be 
quenched by the induction of specific enzymes, such as POD and SOD $(2,24,25)$. The induction of the antioxidative enzymes is one of the processes implicated in the regulation of the metal ion concentration in plants.

A cadmium concentration of $3 \mathrm{mg} \mathrm{kg}^{1}$, as well as nickel concentration $50 \mathrm{mg} \mathrm{kg}{ }^{1}$ in the soil are considered to be a threshold value for plant toxicity, according to the criteria of the Economical Board of the United Nations for Europe and International Union of Biological Sciences (26). Our results show that, in case of spruce seedlings, soil threshold $\mathrm{Cd}$ and $\mathrm{Ni}$ concentrations mostly do not cause any significant changes in the part of the oxidative metabolism, as measured by induced changes in POD and SOD activity, and isoenzyme pattern. Higher metal concentrations, in case of $\mathrm{Cd}$ and $\mathrm{Ni} / \mathrm{Cd}$ treatment induced an increase in oxidative metabolism (Figures 3, 4), probably caused by an increased quantity of free radicals and reactive oxygen forms $(25,27)$. The activity change was followed with a change of the POD isoenzyme pattern (Figure 5), as well as with accumulation of metals in the needles (Figure 1). Wilting of the needles was an exogenous symptom of toxicity in the plants treated with higher metal concentrations. Our results show that initial increase of one part of antioxidative defense system is related to de novo synthesis of the new POD isoenzymes. On the other hand, the absence of the significant increase of the antioxidative enzyme activities in response to the prolonged nickel stress (Figures 3,4), despite of the increased nickel quantity in the needles may show that this metal alone did not exert a considerably toxic effect on the plants. A trend of decrease in POD activity 60 days after treatment with both $\mathrm{Cd}$ and $\mathrm{Ni} / \mathrm{Cd}$ (Figure 3) in comparison with untreated plants may be a consequence of the prolonged exposure to higher metal concentrations. These results show that $\mathrm{Cd}$ is more harmful to the plant metabolism comparing to nickel.

CCA is the most popular ordination method, which is designed for community ecology. It ordinates both species and communities along one or more environmental factors. In this study we applied CCA in order to relate increased concentration of $\mathrm{Ni}$ and $\mathrm{Cd}$ to defense response of plants. Results of CCA show that $\mathrm{Ni}$ and $\mathrm{Cd}$ influence synergistically on measured parameters after the treatment with $\mathrm{C} 1$ and $\mathrm{C} 2$ metal concentration, while after treatment with C3 they have antagonistic influence. During the treatment with any combination of $\mathrm{Ni}$ and $\mathrm{Cd}$ concentrations, $\mathrm{Cd}$ had a positive influence on the POD and SOD activity (Figure 6). The strongest effect of $\mathrm{Cd}$ on the measured parameters was in the case of the highest applied concentration C3, while Ni showed a uniform effect on the parameters in all treatments.
CCA clearly indicates that increased concentration of heavy metals affects POD and SOD activities. Consequently, the soluble POD and SOD activities can be used as parameters for the assessment of $\mathrm{Ni}$ and $\mathrm{Cd}$ induced damage to the studied plants. CCA directly shows that the effect of $\mathrm{Cd}$ on the measured parameters is generally more pronounced comparing to the effect of Ni (Figure 6). The strong phytotoxic effect of this metal is well known (28). Since the measured parameters are in good correlation with $\mathrm{Cd}$ accumulation in the needles treated both with $\mathrm{Cd}$ alone and simultaneously with Ni (Figures 1b,c, 3b,c, 4a,b), the toxic effect of $\mathrm{Cd}$ can be evaluated through these parameters in both kinds of treatment.

It would be important to define the physiological threshold of different plants towards different kinds of stress: that would be the stress intensity causing a decrease of oxidative metabolism and physiological functions. It has been indicated that enzyme induction and/or isoenzyme variations may be used as suitable parameters for monitoring of the environmental pollution $(3,29)$. Among higher plants, coniferous trees are proposed to have a particular role in bioindication of the environment, since they indicate the pollution produced over longer time periods (13). Our results showed that in the spruce seedlings, even in case of $21 \mathrm{mg} \mathrm{kg} 1 \mathrm{Cd}$ and $500 \mathrm{mg} \mathrm{kg} 1 \mathrm{Ni}$ in the soil, and corresponding $46 \mathrm{mg} \mathrm{kg} 1 \mathrm{Cd}$ and $3244 \mathrm{mg} \mathrm{kg} 1$ $\mathrm{Ni}$ in the needles, mechanisms of antioxidative defense were active. Our results also show that the kind of polluting metal is as much important as the type of treatment (separated or combined).

According to our data, enzymes of antioxidative defense SOD and POD may be used in prediction and estimation of the damaging effect of heavy metals to the plants. Our results indicate that POD isoenzymic pattern is even more sensitive to the early changes in the oxidative metabolism, comparing to the POD activity. Although studies on the physiology and biochemistry of metal toxicity are difficult, our data support the concept that monitoring of the oxidative metabolism parameters in different plant species should be an integral part of the evaluation and quantification of the effect of metal stress on plants.

Acknowledgements. Grant 1911 (Cellular response to pollution stress in trees. Possibility of application in biomonitoring of the environment) in 2002 and 1901 (Biophysical studies of the structure and functional organization of the biological systems) in 20002001 from the Ministry of Science and Technology of the Republic of Serbia supported this study. 


\title{
TOKSIČNOST NIKLA I KADMIJUMA U ČETINAMA SMRČE: UTICAJ ZASEBNIH I KOMBINOVANIH TRETMANA NA PEROKSIDAZNU I SUPEROKSID-DISMUTAZNU AKTIVNOST
}

\author{
Ksenija Radotić1, Tanja Dučić1, Radivoje Prodanović2, Zoran Vujčić2, \\ Branko Karadžić3, Suetlana Antić-Jovanović4 \\ ${ }^{1}$ Centar za multidisciplinarne studije, Univerzitet u Beogradu, Kneza Višeslava 1, Beograd \\ 2 Biohemijski fakultet, Univerzitet u Beogradu \\ 3Institut za biološka istraživanja »Siniša Stanković«, Beograd \\ 4Poljoprivredni fakultet, Univerzitet u Beogradu
}

\begin{abstract}
Kratak sadržaj: Proučavana je aktivnost slobodnih peroksidaza i superoksid-dismutaza, izoenzimski profil peroksidaza i sadržaj metala u četinama dvogodišnjih smrča gajenih na zemljištu u koje su dodavani kadmijum i nikl u koncentracijama 3 do $30 \mathrm{mg} \mathrm{kg}{ }^{1}$ i 50 do 500 mg kg ${ }^{1}$ respektivno. Metali su dodavani na dva načina: zasebno i istovremeno. Kinetika usvajanja metala i ukupna akumulirana količina zavisili su od vrste tretmana. U tretiranim izdancima došlo je do povećanja peroksidazne aktivnosti u slučaju tretmana kadmijumom i nikl/kadmijumom, kao i superoksid-dismutazne aktivnosti u toku tretmana nikl/kadmijumom, u odnosu na netretirane biljke. Istovremeno je došlo do promene izoenzimskog sastava peroksidaza. Koncentracija akumuliranih metala u četinama je bila u dobroj korelaciji sa enzimskim aktivnostima. Pokazano je da je uticaj kadmijuma na merene parametre jači u poređenju sa uticajem nikla. Dobijeni rezultati pokazuju da peroksidazna i superoksid-dismutazna aktivnost i izoenzimski profil peroksidaza mogu da se koriste za procenu kapaciteta jednog dela zaštitnog sistema u izdancima smrče u odnosu na stres izazvan metalima.
\end{abstract}

Ključne reči: slobodni radikali, enzimska indukcija, bioindikacija.

\section{References}

1. Van Assche F, Clijsters H: Effect of heavy metals on enzyme activity in plants. Plant Cell Environ 1990; 13: 195206.

2. Vangronsveld J, Clijsters H. Toxic effects of metals. In: Farago ME ed. Plants and the Chemical ElementsBiochemistry, Uptake, Tolerance and Toxicity. VCH, Weinheim, 1994: 149177.

3. Keller T. The use peroxidase activity for monitoring and mapping air pollution areas. Eur J For Pathol 1974; 4: 1119.

4. Cardinaels C, Put C, Van Assche F, Clijsters H. The superoxide dismutase as a biochemical indicator discriminating between $\mathrm{Zn}$ and $\mathrm{Cd}$ toxicity. Arch Internat Physiol Biochem 1984; 9: 2728.

5. Kahle $\mathrm{H}$. Response of roots of trees to heavy metals. Environ Exp Bot 1993; 33: 99119.

6. Grill E, Winnacker E-L, Zenk MH. Occurrence of heavy metal binding phytochelatins in plants growing in a mining refuse area. Experientia 1988; 44: 53940.

7. Gawel JE, Ahner BA, Friedland AJ, Morel FMM. Role for heavy metals in forest decline indicated by phytochelatin measurement. Nature1996; 381: 6465.

8. Polle A, Chakrabarti K. Effects of manganese deficiency on soluble apoplastic peroxidase activities and lignin content in needles of Norway spruce (Picea abies). Tree Physiol 1994; 14: 1191200.
9. Radotić K, Dučić T, Knežević M. Peroxidase activity and isozyme profiles in the leaves of spruce (Picea abies) and black pine (Pinus nigra) from different localities varying in the extent of pollution. Arch. Biol. Sci. 2001; 53: 2332.

10. Ouzounidou G, Ciaporova M, Moustakas M, Karataglis S. Responses of maize (Zea mays L.) plants to copper stress I. Growth, mineral content and ultrastructure of roots. Environ Exp Bot 1995; 35: 167176.

11. Arduini I, Godbold DL, Onnis A. Cadmium and copper uptake and distribution in mediteranean tree seedlings. Physiol Plant 1996; 97: 1117.

12. Radotić K, Dučić T, Mutavdžic D. Changes in peroxidase activity and isoenzymes in spruce needles after exposure to different concentrations of cadmium. Environ Exp Bot 2000; 44: 105113.

13. Mulgrew A, Wiliams P. Biomonitoring air quality using plants. WHO Collaborating Centre for Air Quality Management and Air Pollution control, 2000: ISSN 938 982.

14. ter Braak CJF. Canonical correspondence analysis: A new eigenvector technique for multivariate direct gradient analysis. Ecology 1986; 67: 11671179.

15. Karadžić B,. Šašo-Jovanović V, Jovanović Z, Popović R. »FLORA« a database and software for floristic and vegetation analyzes. In: Tsekos I, Moustakas M. eds. Progress in Botanical Research. Kluwer Academic Publishers, Dodrecht, 1998: 6972. 
16. Weckx JE, Clijsters HMM. Oxidative damage and defense mechanisms in primary leaves of Phaseolus vulgaris as a result of root assimilation of toxic amounts of copper. Physiol. Plant. 1996; 96: 50612.

17. Misra HP, Fridovich I. The role of superoxide-anion in the autooxidation of epinephrine and a simple assay for superoxide dismutase. J Biol Chem 1972; 247: 31705.

18. Bradford MM. A rapid and sensitive method for the quantification of microgram quantities of protein utilizing the principles of protein-dye binding. Anal Biochem 1976; 72: 24854.

19. Csintalan Z, Tuba Z. The effect of pollution on the physiological processes in plants. In: Kov cs M. ed. Biological indicators in environmental protection. Ellis Horwood, New York, 1992: 169191.

20. Meksongsee L, Wongkaew W. Response of peroxidase of water hyacinth to lead pollutant stress. In: Lobarzewski J, Greppin H, Penel C, Gaspar TH. eds. Biochemical, Molecular and Physiological Aspects of Plant Peroxidases. University of Geneva, Geneva, 1991: 4635.

21. Reddy GN, Prasad MNV. Cadmium induced peroxidase activity and isozymes in Oryza sativa. Biochem. Arch. 1992; 8: 1016.

22. Tsang EWT, Bowler C, HJrouart D, Van Camp W, Villarroel R, Genetello $C$ et al.. Differential regulation of su- peroxide dismutases in plants exposed to environmental stress. Plant Cell. 1991; 3: 78392.

23. Bowler C, Van Montagu M, Inzé D. Superoxide dismutase and stress tolerance. Annu. Rev. Plant Physiol. Plant Mol Biol 1992; 43: 83116.

24. Vangrosveld J. Clijsters H. A biological test system for the evaluation of metal phytotoxicity and immobilization by additives in metal contaminated soils. In: Merian E, Heardi W eds. Metal compounds in environment and life (Interrelation between chemistry and biology). Sci Technol Letters, Northwood; vol. 4: 11725.

25. Hippeli S, Elstner EE. Mechanisms of oxygen activation during plant stress: biochemical effects of air pollutants. J Plant Physiol 1996; 48: 24957.

26. International Union of Biological Sciences,. Element concentration cadasters in ecosystems, Progress report, 25th General Assembly: Paris, 1994.

27. Hendry GAF, Crawford RMM. Oxygen and environmental stress in plants an overview. Proc. R. Soc. Edinburgh 1994; 102B: 110.

28. Das P, Samantaray S, Rout GR. Studies on cadmium toxicity in plants: a Review. Environ Pollut 1997; 98: 29 36.

29. Rabe R, Kreeb KH. Enzyme activaties and chlorophyll and protein content in plants as indicators of air pollution. Environ Pollut 1979; 19: 119136. 